\title{
COMPARATIVE MORPHOLOGY OF THE TONGUE IN FREE-TAILED BATS (CHIROPTERA, MOLOSSIDAE)
}

\author{
Renato Gregorin ${ }^{1}$
}

\begin{abstract}
Descriptive and comparative studies on tongue of nineteen Molossidae, one Mystacinidae, and four Vespertilionidae bats species were carried out. Analysis was restricted to the external morphology, covering general shape of the tongue and its papillae. Types of papillae and their distribution presented considerable intergeneric variation, considering the strictly insectivorous feeding habits of these bats. Distribution of the data of tongue morphology is analyzed and compared with the phylogenetic schemes proposed previously and comments about evolutionary relationships among taxa were done.
\end{abstract}

KEYWORDS. Molossidae, morphology, evolutionary relationships.

\section{INTRODUCTION}

Studies dealing with lingual morphology of bats are numerous when compared to other mammal orders (Park \& Hall, 1951; Greenbaum \& Phillips, 1974; Howell \& Hodgkin, 1976; Griffiths, 1982; Uieda, 1986; Griffiths \& Criley, 1989; Gimenez et al., 1996; WetTERER et al., 2000). Most of these studies had focused on family Phyllostomidae and recently they have conveyed on both descriptive and phylogenetic approaches (GrifFiths, 1982; Gimenez et al., 1996; WetTerer et al., 2000). Particularly to molossid bats nothing has been published about morphology of the tongue but other anatomical studies for the Neotropical molossids include analysis of glans penis (RYAN, 1991a, b) and hair structure (STAADEN \& JONES, 1997). They have contributed to elucidate the evolutionary relationships and variation among and within molossid taxa, and also raised interesting questions when these data disagreed with the previously known hypothesis based on dentition (LEGENDRE, 1984; HAND, 1990), skull and external morphology (FreEMAN, 1981a; KoOPMAn, 1994). FreEMAN (1979) has proposed scenarios to evolution of the feeding habits in molossid bats based on cranial and dentary attributes under a morpho-functional approach. This author has suggested a dichotomic arrangement to the molossids consisting in beetle- and moth-eating. Lingual morphology also can be useful in elucidating dietary preferences and evolutionary patterns of feeding habits in molossids.

1. Departamento de Zoologia e Botânica, Universidade Estadual Paulista, Rua Cristóvão Colombo, 2265, 15054-000, São José do Rio Preto, SP, Brasil. (rgregorin@hotmail.com) 
The goal is to provide information on molossid tongue anatomy using scanning electron microscope and to make some assumptions about evolutionary relationships and feeding specialization among studied taxa.

\section{MATERIAL AND METHODS}

Studied specimens were housed in the American Museum of Natural History, New York (AMNH), Lousiana State University (LSU), Coleção do Laboratório de Zoologia de Vertebrados, Faculdade de Filosofia Ciências e Letras de Ribeirão Preto (LZV), and Museu de Zoologia, Universidade de São Paulo, São Paulo (MZSP). Analysis employing stereo and scanning electron microscopy included thirty-eight specimens representing nineteen molossid species, mostly Neotropical: Chaerephon jobensis (Miller, 1902) (AMNH 208785), C. pumilus (Cretzschmar, 1826) (MZSP 15239, 15241), Eumops auripendulus (Shaw, 1800) (MZSP 7298, 20418), E. bonariensis (Peters, 1874) (AMNH 235406, MZSP 6495), E. glaucinus (Wagner, 1843) (MZSP 28489), E. perotis (Schinz, 1821) (MZSP 15660, 15663), Molossops (Cynomops) abrasus (Temmincki, 1827) (MZSP 15655), M. (Molossops) temminckii (Burmeister, 1854) (LZV 94035, MZSP 15410), M. (Neoplatymops) mattogrossensis (Vieira, 1942) (MZSP 19887, 19888, 19890), Molossus (molossus) (Pallas, 1766) (MZSP 7804, 8333, 8337, 15582, 26410), M. rufus (E. Geoffroy Saint-Hilaire, 1805) (MZSP 15452, 15470, 15550), Mops condylurus (Smith, 1833) (MZSP 15243, 15244), M. mops (Blainville, 1840) (AMNH 257078), M. spurrelli (Dollman, 1911) (AMNH 257076), M. thersites (Thomas, 1903) (AMNH 239430, 239434), Mormopterus beccarii Peters, 1881 (AMNH 194649), M. kalinowski (Thomas, 1893) (AMNH 165626), Nyctinomops laticaudatus (E. Geoffroy SaintHilaire, 1805) (AMNH 144383, MZSP 7941) and Tadarida brasiliensis (I. Geoffroy Saint-Hilaire, 1824) (MZSP 8254, 15444, 15445, 22458). For comparison one Mystacinidae and four vespertilionid species were studied: Antrozous pallidus (Le Conte, 1856) (AMNH 15019), Lasiurus cinereus (Beauvois, 1796) (MZSP 1324, 15257), Myotis nigricans (Schinz, 1821) (MZSP 15089, 15098, 15099), Mystacina robusta Dwyer, 1962 (AMNH 214243), and Tomopeas ravus Miller, 1900 (LSU 25087).

Tongues were removed from fluid-preserved specimens through an incision at the root of the tongue. Initially, tongues were compared using stereomicroscopy, for the study of large series and intraspecific variation of the general shape and papillae distribution. Posteriorly, scanning electron microscopy was employed in order to study the papillae structure. The material was initially washed in distilled water using ultrasound equipment to clear the tongue surface. Then, the tongues were bathed in an Osmium Tetroxide 1\% solution at $4^{\circ} \mathrm{C}$ and Glutaldeid 3\% solution. The classification and nomenclature of the papillae types and regions of the tongue follows Gimenez et al. (1996), except for the fungiform ones, which I have divided into two classes based on their position over the tongue surface: dorsal or lateral. Lingual papillae were classified according to the following scheme: gustative, including vallate and fungiform, or mechanical comprising basal, postero-median, scalelike, and horny.

\section{RESULTS}

In molossids, tongues are relatively short, similarly to most of the microchiropteran families. Length of tongue from root to apex range from 45 to $55 \%$ of total length of skull. A prominent median-dorsal lobe with a basal groove is present in all molossids studied (figs. 1,2), and has been considered as apomorphic to the family. Molossids present two gustative papillae types, vallate and fungiform, and three mechanical ones: basal, scalelike, and postero-median conical. Mechanical horny papillae, which are frequently found in phyllostomids and vespertilionids, are lacking in the free-tailed bats. In the gustative group, only one medial pair of vallate papillae are situated in the proximal region of the tongue ahead of the root (fig. 1). Fungiform papillae are globose and fleshy, and are restricted to the lateral surface and mid-dorsal region, ahead the vallate papillae (figs. 18). This distributional pattern of fungiform papillae in molossids differs from that of the 
vespertilionid taxa analyzed, because the latter presents scattered papillae over the whole dorsal lingual surface (fig. 9). Mechanical papillae cover the entire dorsal and lateral surfaces of the tongue. Scale-like papillae cover the latero-dorsal surface on the anterior half of the tongue, from the tip to the median lobe. In molossids, these papillae are posteriorly directed, pointed (except Tadarida brasiliensis), and larger near the tip of the tongue than on the median region, close to the lobe. The postero-median conical papillae are distributed from lobe to the vallate ones, and back and outward directed (fig. 1). Postero-median papillae are generally monofid and pulpier than scale-like ones. In molossids, they are larger at the lobe than at the basal region, but this difference varies within the family. Basal papillae are restricted to latero-posterior region of the tongue and arranged beside the vallate papillae; they are monofid, smooth, and present a cushion outline in contrast with those of other families of Chiroptera, which are typically conical. Basal papillae in molossids are smaller than in the Vespertilionoidea and Phyllostomidae taxa (figs. 1-4).

Comparative tongue morphology among molossid taxa. Molossops (Molossops) present the basic pattern of papillae described above. The postero-median papillae are very large over the lobe region (figs. 1, 3). Molossops (Neoplatymops) mattogrossensis and Molossops (Molossops) share the maximum degree in development of postero-median papillae (figs. 3, 7), and the conical shape instead of the quadrangular and centrally curved one observed in Molossops (Cynomops) and Tadarida brasiliensis (figs. 1, 3). These conditions are considered here as a derived state, indicating the close relationships among species of Molossops. Fungiform papillae are distributed regularly in the lateral surface from the middle to posterior region of the tongue, and they are proportionally larger in these genera than in other Molossidae and Vespertilionidae taxa (Eumops auripendulus, E. glaucinus, E. perotis, Lasiurus cinereus and Myotis nigricans). Dorsal region between the lobe and vallate papillae is slightly naked, with some fungiform papillae spread irregularly. A similar pattern of papillae is present in Mormopterus beccarii and M. kalinowski.

Nyctinomops Miller, 1902, Mops Lesson, 1842, and Chaerephon Dobson, 1847: species of these genera present the square postero-median papillae on the lobe, and these are smaller than those ones showed by Molossops temminckii and M. (Neoplatymops) mattogrossensis. A peculiar characteristic observed in these taxa is the presence of five or six large fungiform papillae spread ahead of the vallate. Nyctinomops laticaudatus presents a quite linear arrangement in dorsal fungiform papillae.

Tadarida brasiliensis: the tongue is longer than in other analyzed molossid species, and the papillae arrangement follows that of the family. The scale-like papillae present a conspicuous, very fringed structure in the tip of the tongue (figs. 9-11), which modifies in an almost monofid papillae in the posterior region. Fringed papillae are well distributed in vespertilionid taxa. The lateral fungiform papillae are small and disposed regularly in two distinctive lines: a shorter and upper row closer to the lobe, and a ventral and longer row, from the tip to middle of the tongue (fig. 8). This lateral arrangement of fungiform papillae was also recorded in Mops mops and it is here considered as derived.

Molossus E. Geoffroy, 1805: species present reduced and flattened postero-median papillae (fig. 6) with similar size along all posterior region of the tongue. There are fungiform papillae spread scarcely over the mid-dorsal surface ahead of the vallate papillae. Lateral fungiform papillae have intermediate size and an irregular arrangement 

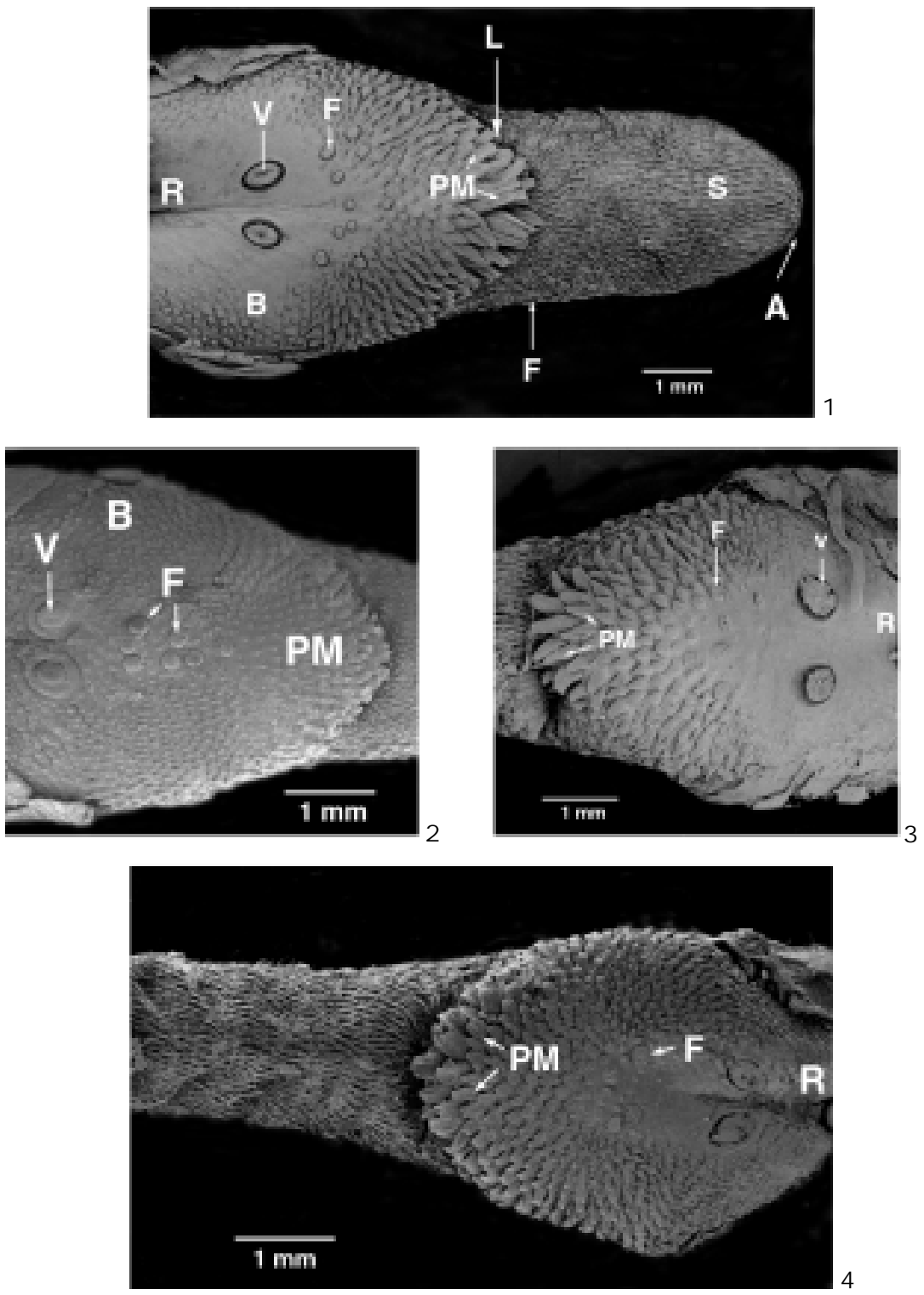

Figs. 1-4. Tongue of molossid bats, dorsal view. 1, Molossops (Cynomops) abrasus, shows the anterior and posterior regions limited by the lobe, and the several papilla types; 2, Tadarida brasiliensis, with prominent dorsal fungiform papillae; 3, Molossops (Molossops) temminckii, conical and developed postero-median papillae over the lobe; 4, Eumops bonariensis, weak dorsal fungiform papillae (A, apical region of the tongue; B, basal papillae region; F, fungiform papillae; L, mid-dorsal lobe; PM, postero-median papillae; $\mathrm{R}$, root of the tongue; $\mathrm{S}$, scale-like papillae; V, vallate papillae). 
(fig. 6). The basal papillae are larger and more conical than in other analyzed molossid taxa. Eumops Miller, 1906: species of this genus, except for E. bonariensis, presented the simplest lingual structure among the molossids bats. In general, postero-median conical papillae are small, rounded like a cushion. Fungiform papillae over dorsal surface are lacking, and the lateral ones are small, abundant and irregularly arranged. Eumops bonariensis shows a distinctive structure within the genus, because the species has an elongated tongue and large postero-median papillae over the lobe (fig. 4).

\section{DISCUSSION}

The number of types of papillae on the tongue of Molossidae, as well as Vespertilionoidea, is reduced and presents a simpler structure when compared to Phyllostomidae. All taxa of the former groups are strictly aerial insectivorous, contrasting with the diverse feeding habits known to the later group, which include carnivory, hematophagy, nectarivory, folivory, frugivory, and insectivory (GARDNER, 1977; FERRAREZZI
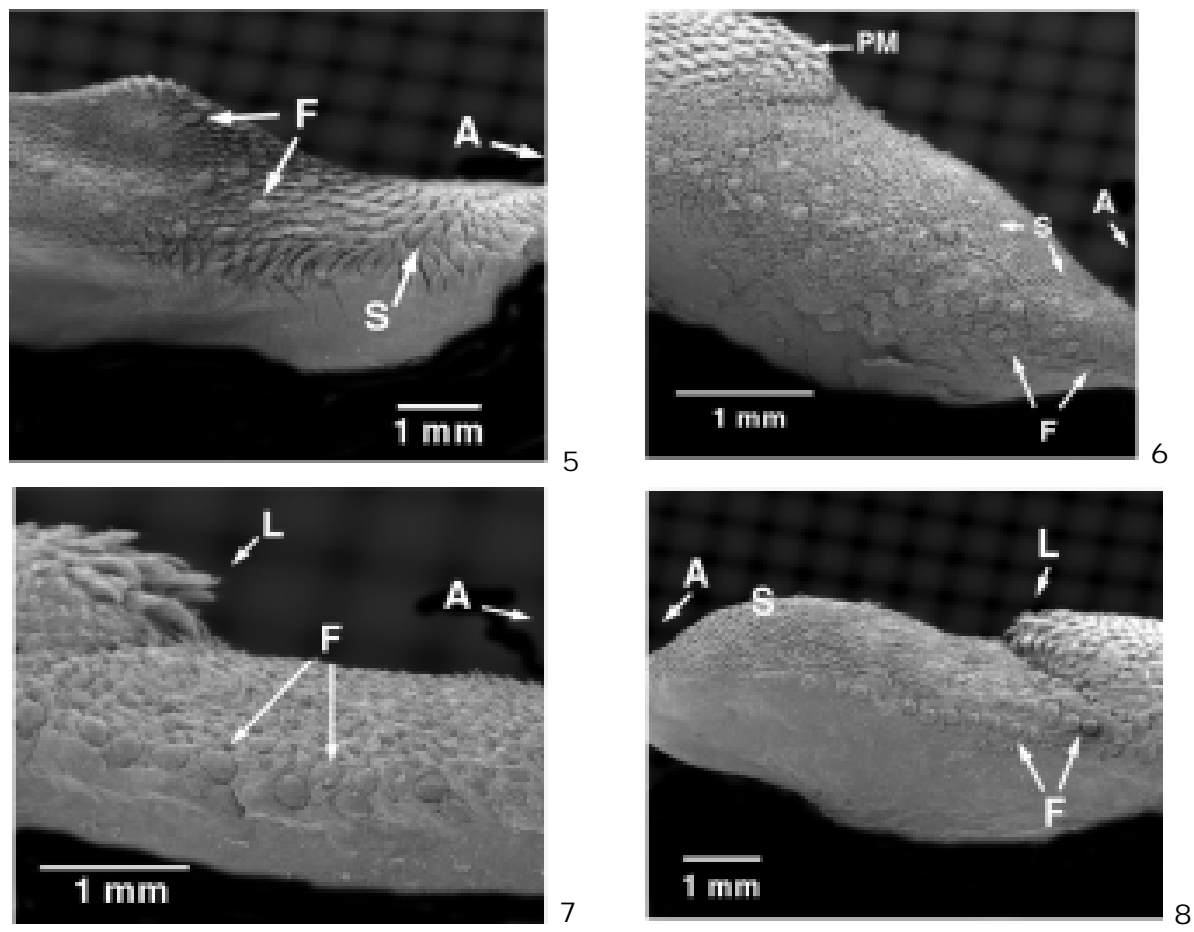

Figs 5-8. Mid-anterior portion of the tongues in bats, lateral view. 5, Lasiurus cinereus (Vespertilionidae), with no latero-anterior fungiform papillae; 6, Molossus molossus (Molossidae), fungiform papillae spread along the lateral side of the tongue. Linear arrangement of fungiform papillae on lateral surface of the tongue: 7, Molossops (Neoplatymops) mattogrossensis; 8, Tadarida brasiliensis (Molossidae) (A, orientation of the apical region; F, fungiform papillae; L, mid-dorsal lobe; PM, postero-median papillae; S, scale-like papillae). 

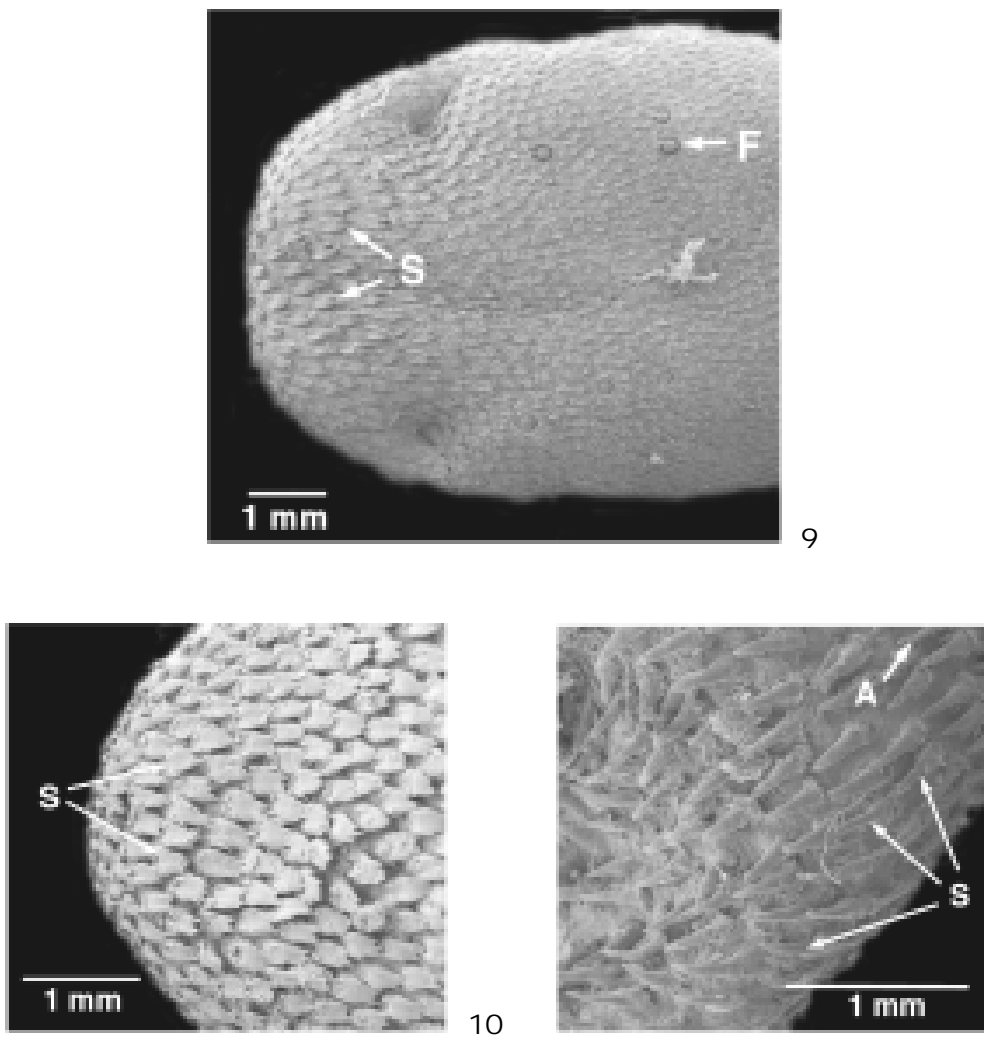

11

Figs. 9-11. Distal edge (apex) of tongue in bats, dorsal view. 9, 10. Fringed scale-like papillae: 9, Lasiurus cinereus (Vespertilionidae); 10, Tadarida brasiliensis (Molossidae). Conical and monofid scale-like papillae: 11, Molossops temminckii (Molossidae) (A, orientation of the apical region; F, fungiform papillae; $\mathrm{S}$, scale-like papillae).

\& Gimenez, 1996). This diversity of feeding habits directly reflects on the tongue morphology of phyllostomids. The tongue of microchiropterans has usually flat dorsal surface, while molossid bats present a prominent mid-dorsal lobe. Individuals of Tomopeas ravus, Antrozous pallidus and Lasiurus cinereus present an elevation on the mid region of the tongue, but this condition differs from that showed by molossids in lacking the basal groove. Thus, that condition in free-tailed bats is exclusive and considered derived.

Another derived trend in the molossid tongue is to the reduction in number and, mainly, in the occurrence areas of fungiform papillae on the tongue. While in vespertilionid bats these papillae are minute and spread over all dorsal and lateral surfaces of the tongue, molossid bats have larger fungiform papillae ordered in two specific areas over the tongue surface: a posterior area situated between the median lobe and the root, and at the lateral surface, from the lobe to the apical region. Also, lateral vallate papillae, which are frequent in chiropteran families (WETTERER et al., 2000), are lacking in molossids. 
Size reduction and the rounded shape of basal papillae are restricted to molossids and may also be considered a derived trait. Basal papillae in Lasiurus Gray, 1831 are typically conical and this form was also observed in Myotis nigricans and Tomopeas ravus. The complexity and disposition of the lingual papillae in Mystacina robusta strongly contrasts with that showed by molossid and vespertilionid bats, corroborating its remote relationships with molossid bats as proposed recently by Simmons (1998). The papillae present in $M$. robusta remind more those of Phyllostomidae, implying in phylogenetic proximity between both groups (PIERsON et al., 1986; KIRSCH et al., 1998).

Inferences about kinship among molossid genera based on lingual morphology revealed close relationship between Molossops (Neoplatymops) mattogrossensis and Molossops spp., and more remotely, with Mormopterus beccarii and M. kalinowskii. These species share two distinctive characters states: the largest fungiform and posteromedian conical papillae at the lobe. This condition corroborates the affinity of taxa based on external and skull morphology (FreEman, 1981a; KoOPMAN, 1994), but not on the dentition (LEGENDRE, 1984). Evolutionary relationships in molossids proposed by FREEMAN (1981a) were based on skull, dentition, and external morphology. This author has proposed two distinctive branches to the family: one composed by Molossops (including Cynomops Thomas, 1920, Neoplatymops Peterson, 1965, and Cabreramops Ibanéz, 1980 as subgenera), Mormopterus (including Platymops Thomas, 1906 and Sauromys Roberts, 1917 as subgenera), Myopterus E. Geoffroy, 1818, and Cheiromeles Horsfield, 1824. The other lineage includes the remaining taxa, with Tadarida being the most basal in this branch, and Molossus and Eumops being closely related and the most derived of them. The present data partially corroborates FREEMAN (1981a), who considered Tadarida as a basal taxon. Indeed, this species presents a more elongated tongue and fringed scale-like papillae as in vespertilionids, supporting their primitive condition.

Results present some divergence when the optimization of tongue characters is done on the phylogenetic tree provided by FREEMAN (1981a). Both scale-like monofid and lateral fungiform papillae regularly arranged must have appeared twice in the evolutionary history of the family whether following Freeman tree. Intra-generic variation was recorded for Mops and Eumops. In the former, M. mops showed a linear arrangement of fungiform lateral papillae similar to that one found in T. brasiliensis and very different from that recorded to the remaining species analyzed for the genus. Within Eumops, E. bonariensis showed an elongated tongue and developed postero-median papillae over the lobe. These characteristics are lacking in other species of Eumops studied here. This evident morphological difference of M. mops and E. bonariensis in relation to their sister species has been supported by skull, face, and dentition characters (FreEMAN, 1981a; LEGENDRE, 1984), corroborating the high level of divergence inside both genera.

Data presented here also permit to divide the molossid taxa in two groups based on the postero-median conical papillae morphology: one group presenting high variation in size, with accentuated development of the papillae over the lobe instead of those ones present in the base of tongue, and another group showing a homogeneity in size of these papillae. The former includes T. brasiliensis, M. condylurus, C. pumilus, $N$. laticaudatus, M. temminckii, E. bonariensis and M. (Neoplatymops) mattogrossensis. The second group comprises most of the Eumops species and Molossus. Differences between both groups can be related to food manipulation and to the ingestion process. FREEMAN $(1979,1981 b)$ divided the molossids in two classes based on food consumption: 
the beetle- and moth-eating bats. A correlation considering the distribution of papillae in both groups defined by FREEMAN (1981b) was more positive, in which the presence of developed postero-median papillae and a thin jaw, added to the reduced coronoid process in the molossid species, are coincident. According to FrEEMAN $(1979,1981 \mathrm{a}, \mathrm{b})$, taxa that show a fragile jaw, exert less force in the bite to ingest soft insects like moths. Perhaps, more developed mechanical papillae aid the mastigatory process, food manipulation and ingestion. Taxa that present smaller mechanical papillae (Molossus and most of Eumops species) also have robust jaws and enlarged teeth, and consequently, exert a stronger bite and more crushing on the insect exoskeleton. This correlation is also partially positive when comparing the several species of Eumops. FreEMAN (1981a) divided the genus into three classes based on jaw thickness. Eumops bonariensis presents a thin jaw, while the remaining species present median or robust jaw. Eumops bonariensis presents the mid lobe covered by well-developed mechanical papillae. There are two exceptions to this positive correlation: E. perotis and Nyctinomops laticaudatus, which show developed mechanical papillae and thin jaw. Further studies, mainly on Old World molossid bats, are requested for more complete comparative approach, and for more robust and conclusive propositions about phylogenetic relationships among genera based on tongue characters.

Acknowledgments. To Mario de Vivo (MZSP) and Nancy B. Simmons (AMNH) for permission to study the material. To Dr. Alberto F. Ribeiro and Enio Matos (Microscopia Eletrônica, Instituto de Biociências, USP), Miriam Matos and Lara M. Guimarães (MZSP) for support in scanning microscopy analysis; to Alexandre R. Percequillo (MZSP) and Francisco Langeani Neto (UNESP) for criticisms on the manuscript, and Eliana A. Gimenez (UFPB) for discussion about tongue morphology. To FAPESP (proc. $n^{\circ}$ : 96/2140-7 and 01/10292-1), and partially by Collection Study Grant Program $(\mathrm{AMNH})$.

\section{REFERENCES}

Ferrarezzi, H. \& Gimenez, E. A. 1996. Systematic patterns and the evolution of feeding habitats in Chiroptera (Archonta: Mammalia). J. Comp. Biol., Ribeirão Preto, 1(3/4):75-94.

Freeman, P. W. 1979. Specialized insectivory: beetle-eating and moth-eating molossid bats. J. Mammal., Lawrence, 60(3):467-479.

1981a. A multivariate study of the family Molossidae (Mammalia, Chiroptera): morphology, ecology, evolution. Fieldiana, Zool., Chicago, 7:1-173.

1981b. Correspondence of food habitats and morphology in insectivorous bats. J. Mammal., Lawrence, 62(1):166-173.

Gardner, A. L. 1977. Feeding habitats. Spec. Publ. Mus. Texas Tech. Univ., Lubbock, 13:293350.

Gimenez, E. A; Ferrarezzi, H. \& Taddei, V. A. 1996. Lingual morphology and cladistic analysis of the New World nectar-feeding bats (Chiroptera: Phyllostomidae). J. Comp. Biol., Ribeirão Preto, 1(1-2):41-63.

Greenbaum, I. F. \& Phillips, C. J. 1974. Comparative anatomy and general histology of tongues of long-nosed bats (Leptonycteris sanborni and L. nivalis), with reference to infestation of oral mites. J. Mammal., Lawrence, 55(3):489-504.

Griffiths, T. A. 1982. Systematics of the New World nectar-feeding bats (Mammalia, Chiroptera), based on the morphology of the hyoid and lingual regions. Am. Mus. Novit., New York, (2742): $1-45$.

Griffiths, T. A. \& CRILEY, B. B. 1989. Comparative lingual anatomy of the bats Desmodus rotundus and Lonchophyla robusta (Chiroptera: Phyllostomidae). J. Mammal., Lawrence, 70(3):608603. 
HAnd, S. J. 1990. First Tertiary molossid (Microchiroptera: Molossidae) from Australia: its phylogenetic and biogeographic implications. Mem. Queensl. Mus., Brisbane, 28:175-192.

Howell, D. J. \& Hodgkin, N. 1976. Feeding adaptations in the hairs and tongues of nectar-feeding bats. J. Morphol., New York, 148:329-336.

Kirsch, J. A; Hutcheon, J. M. et al. 1998. Affinities and historical zoogeography of the New Zeland short-tailed bat, Mystacina tuberculata Gray, 1843, inferred from DNA-hybridization comparisons. J. Mammal. Evol., New York, 5(1):33-64.

Koopman, K. F. 1994. Chiroptera: systematics. Handbuch der Zoologie, Mammalia, part 60. Berlin, Walter de Gruyter. v. 8, p.217.

LEGENDRE, S. 1984. Étude odontologique des représentants actuels du groupe Tadarida (Chiroptera, Molossidae). Implications phylogénetiques, systématiques et zoogeographiques. Revue suisse Zool., Genève, 91(2):399-442.

Park, H. \& Hall, R. 1951. The gross anatomy of the tongues and stomachs of eight New World bats. Trans. Kans. Acad. Sci., Topeka, 54(1):64-72.

Pierson, E. D; SARich, V. M. et al. 1986. A molecular link between the bats of New Zeland and South America. Nature, Lancaster, 323:60-63.

Ryan, J. M. 1991a. Morphology of the glans penis in four genera of molossid bats (Chiroptera: Molossidae). J. Mammal., Lawrence, 72(4):658-668.

1991b. Comparative morphology of the glans penis in Molossuss, Promops, and Eumops (Chiroptera: Molossidae). Bull. Am. Mus. nat. Hist., New York, 206:122-137.

Simmons, N. B. 1998. A reappraisal of interfamilial relationships of bats. In: Kunz, T. H. \& Racey, P. A. eds. Bat biology and conservation. Washington, Smithsonian Institution. p.1-54

StaAden, M. J. van \& Jones, J. K., JR. 1997. Comparative morphology of dorsal hair of New World bats of the family Molossidae. In: Arroyo-Cabrales, J. \& Polaco, O. J. eds. Homenaje al Profesor Ticul Álvarez. Mexico, Instituto Nacional de Antropología e Historia. p.373-391.

UiEDA, W. 1986. Aspectos da morfologia lingual das três espécies de morcegos hematófagos (Chiroptera, Phyllostomidae). Revta bras. Biol., Rio de Janeiro, 46(3):81-587.

Wetterer, A. L; Rockman, M. V. \& Simmons, N. B. 2000. Phylogeny of phyllostomid bats (Mammalia: Chiroptera): data from diverse morphological systems, sex chromosomes, and restriction sites. Bull. Am. Mus. nat. Hist., New York, 248:1-200.

Recebido em 08.07.2002; aceito em 13.01.2003. 